\title{
Impact of within-row plant spacing and fixed fruit setting on yield and quality of rockmelon fruit cultivated by drip irrigation in a greenhouse
}

\begin{abstract}
Experiments were conducted in a ventilated greenhouse located in a commercial farm $\left(2^{\circ}\right.$ $\left.56 " \mathrm{~N}, 101^{\circ} 54 " \mathrm{E}\right)$ at Broga, Malaysia from 2014 to 2015. The objective of this study was to evaluate the interaction between within-row plant spacing and fruit-set position on the yield and quality of 'Glamour' rockmelon fruit. Rockmelon was grown at $1.57 \mathrm{~m}$ between rows with $0.15 \mathrm{~m}, 0.30 \mathrm{~m}$, and $0.60 \mathrm{~m}$ of within-row plant spacing. The plants were fixed to set fruit at T1 (one fruit, 1-7 lateral branches), T2 (one fruit, 8-14 lateral branches), T3 (two fruits, 1-7 lateral branches), and T4 (two fruits, 8-14 lateral branches). As within-row plant spacing decreased from $0.30 \mathrm{~m}$ to $0.15 \mathrm{~m}$, yield per ha was increased by $58.1 \%$, and a 3.7fold increase in yield was seen from $0.60-\mathrm{m}$ to $0.15-\mathrm{m}$ spacing. Total soluble solids $\left(11.96^{\circ}\right.$ Brix) and total carbohydrate content (86.60 g GE $100 \mathrm{~g} \mathrm{DW})$ were highest at a plant spacing of $0.60 \mathrm{~m}$. Our results demonstrated that the interaction between $0.30-\mathrm{m}$ within-row plant spacing with two fruits set at 8-14 lateral branches showed the most commercially viable outcome in fresh fruit weight as these conditions produced two fruits with an average fruit weight of $2.20 \mathrm{~kg}$ per fruit.
\end{abstract}

Keyword: Biochemical assay; Commercial; Fresh fruit weight; Fruit quality; Glamour rockmelon; Lateral branch 